\title{
RANCANG BANGUN ALAT PENANAM BENIH PADI BERBASIS ARDUINO NANO
}

\author{
Dody Candra Kumara ${ }^{1}$, Wirdha, S.Si.,M.Pd ${ }^{2}$, Jumaddil Khair ${ }^{3}$ \\ ${ }^{1,2}$ Politeknik Palu \\ ${ }^{3}$ Politeknik Industri Logam Morowali \\ Email: dody_candra@gmail.com
}

\begin{abstract}
This research activity aims to facilitate farmers in the process of planting rice seeds in order to increase agricultural extensification. In this research we use the method of hardware progaming research. This tool is also operated wirelessly by the controller. After undergoing several stages, this research was successfully completed so that the rice seed planter was able to be used by farmers.
\end{abstract}

Keywords: tools, planters, seeds, extensification, agriculture.

\section{PENDAHULUAN}

\subsection{Latar Belakang}

Dalam bidang pertanian penanaman merupakan kegiatan terpenting, karena penanaman menetukan hasil dari pertanian itu sendiri. Kita semua tahu bahwa beras adalah makanan pokok seluruh rakyat Indonesia. Namun faktanya produktifitas beras yang tidak memadai masih menjadi momok utama di bidang pangan Indonesia, dengan banyaknya permintaan pasar namun teknik penanaman yang cukup tertinggal dari Negara lain maka dari itu Indonesia masih harus mengimpor beras dari luar.

Menurut data FAO menunjukkan perkiraan jumlah penduduk dunia pada tahun 2030 mencapai 3 miliyar. Pada tahun 2015 sebanyak 580jt penduduk akan mengalami kekurangan pangan, perhitungan ini menunjukkan bahwa indonesia yang pada saat ini menempati posisi ke-empat sebgai Negara yang memiliki jumlah penduduk terbanyak berkemungkinan besar mengalami kekurangan pangan di masa depan.

Mayoritas petani saat ini masih menggunakan cara tradisional dalam penanaman bibit padi yang mengakibatkan banyak menguras tenaga, waktu, dan pengeluaran yang banyak. Hal itu merupakan salah satu penyebab harga beras kita kalah bersaing dengan harga beras impor yang pada dasar nya kualitas beras kita lebih baik, dan dari segi waktu sangat kurang bila melihat luas sawah. Umumnya buruh tani yang biasanya bekerja sebagai penanam padi bisa bekerja selama 1 jam rata-rata mampu menanam bibit padi seluas $100 \mathrm{~m} 2$ tanpa berhenti. Dengan biaya di borong 80 ribu rupiah per $600 \mathrm{~m} 2$.

\subsection{Rumusan Masalah}

1. Bagaimana menciptakan alat yang dapat memudahkan petani dalam proses menanam padi.

2. Bagaimana menerapkan alat tersebut dengan menggunakan pengendalian secara wireless agar petani dapat mengoperasikannya dengan lebih mudah.

\subsection{Tujuan Penelitian}

1. Mempermudah aktivitas petani dalam hal menanam benih padi.

2. Meningkatkan proses penanaman benih padi sehingga bisa sejalan dengan perkembangan teknologi.

\subsection{Manfaat Penelitian}

1. Membantu petani dalam mengolah lahan pertaniannya yakni penanaman benih padi.

2. Menjadikan proses penanaman bibit padi menjadi lebih efektif, efesien, dan produktif.

3. Menjadi motivasi bagi petani tradisional untuk menggunakan inovasi baru demi perubahan dalam upaya ekstensifikasi pertanian. 


\section{TINJAUAN PUSTAKA}

\subsection{Relay}

Relay adalah saklar (Switch) yang di operasikan secara listrik dan merupakan komponen electromechanical (elektromekanikal) yang terdiri dari 2 bagian utama yakni electromagnet (coil) dan mekanikal (seperangkat kontak saklar/switch).
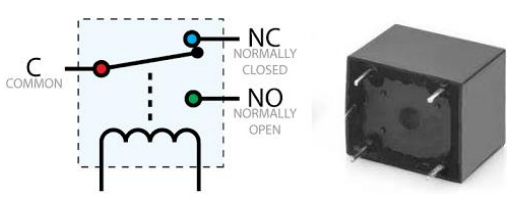

\subsubsection{Arduino Nano}

Arduino Nano adalah salah satu varian dari produk board mikrokontroller keluaran Arduino. Arduino Nano adalah board Arduino terkecil, menggunakan mikrokontroller Atmega 328 untuk Arduino Nano 3.x dan Atmega168 untuk Arduino Nano 2.x. Arduino Nano tidak dilengkapi dengan soket catudaya, tetapi terdapat pin untuk catu daya luar atau dapat menggunakan catu daya dari mini USB port.

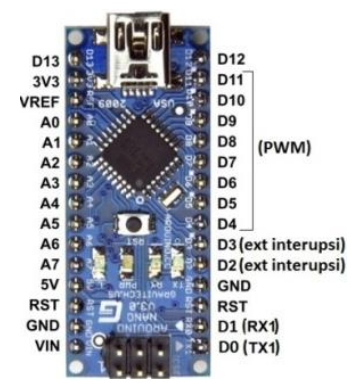

\subsubsection{Daya}

Arduino Nano dapat menggunakan catudaya langsung dari mini-USB port atau menggunakan catudaya luar yang dapat diberikan pada pin30 (+) dan pin29 (-) untuk tegangan kerja $7-12 \mathrm{~V}$ atau pin $28(+)$ dan pin $29(-)$ untuk tegangan $5 \mathrm{~V}$.

\subsubsection{Memori}

Atmega 168 dilengkapi dengan flash memori sebesar 16 kbyte yang dapat digunakan untuk menyimpan kode program utama. Selain dilengkapi dengan flash memori, mikrokontroller ATmega168 dan ATmega328 juga dilengkapi dengan SRAM dan EEPROM. SRAM dan EEPROM dapat digunakan untuk menyimpan data selama program utama bekerja.

\subsubsection{Input dan Output}

Arduino Nano mempunyai 14 pin digital yang dapat digunakan sebagai pin input atau output. Pin ini akan mengeluarkan tegangan $5 \mathrm{~V}$ untuk mode HIGH (logika 1) dan 0V untuk mode LOW (logika 0) jika dikonfigurasikan sebagai pin output. Jika di konfigurasikan sebagai pin input, maka ke 14 pin ini dapat menerima tegangan $5 \mathrm{~V}$ untuk mode HIGH (logika1) dan 0V untuk mode LOW (logika 0).

\section{Metode Penelitian}

Metode penelitian Robot ini menggunakan metode penelitian bidang hardware programing, tahapannya sendiri terdiri dari perancangan, penelitan, pengetesan komponen, desai system mekanik, desain system mekanik, desain sistem listrik, desain softwafe, tes fungsional, perakitan, tes fungsional keseluruhan sistem, dan aplikasi sistem.

\subsection{Waktu dan tempat penelitian}

Penelitian ini dilaksananakan mulai bulan April - Mei 2018. Waktu pelaksanaan dilakukan setiap hari senin - kamis, mulai jam 11.00 - 16.00 WITA di lab. Ipa SMP Al-Azhar Mandiri Palu. Mulai : 14 April 2019 \& Berakhir : 30 Mei 2019

\subsection{Alat dan Bahan}

Adapun alat dan bahan yang digunakan dalam pembuatan alat ini adalah:

Alat :

1. Gurinda, 2. Bor listrik, 3. Solder,

4. Tang potong, 5. Penghisap timah.

Bahan : 
1. Timah, 2. Resistor $330 \mathrm{ohm}, 3$. Transistor bd 139, 4. Relay 6V, 5. PCB matrix IC, 6. Arduino nano, 7. Socket, 8. Kabel / jumper.

\subsection{Desain Sistem}

Perancangan hardware secara umum digambarkan pada urutan rangkaian Prototype seperti terlihat dalam gambar berikut :

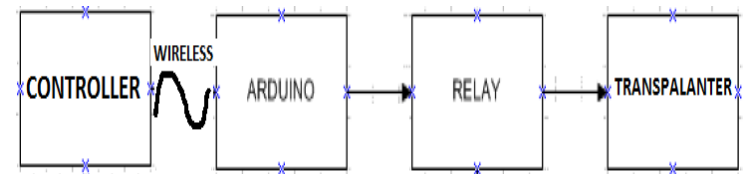

Prinsip kerja :

Alat ini terdiri dari dua bagian yaitu transmitter yang berada pada kendali yang dipegang oleh operator dan bagian penerima yang berada pada robot yang berfungsi untuk menggerakkan robot dengan kendali yang diatur oleh operator. Saat operator menekan tombol pada bagian pemancar, maka bagian pemancarakan mengirimkan sinyal pada bagian penerima yang kemudian akan ditangkap dan diproses oleh arduino nano untuk menggerakkan driver motor dc untuk menggerakkan robot.

\subsection{Algoritma Sistem}

Pembuatan perangkat lunak system harus mengutamakan cara kerja yang efisien berikut flowchart dari desain software yang digunakan. Flowchart program utama terdapat pada gambar berikut ini :

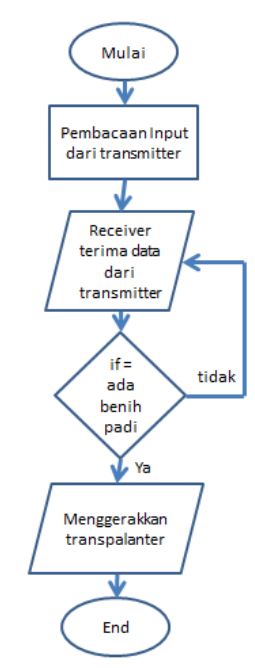

Gambar 3.2. Flow chart program utama

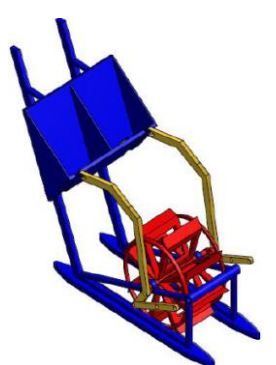

Gambar 3.2. Desain Alat

\subsection{Perancangan Software}

Arduino IDE merupakan kependekan dari Integrated Development Environment, atau secara bahasa mudahnya merupakan lingkungan terintegrasi yang digunakan untuk melakukan pengembangan. Arduino IDE ini dikembangkan dari software Processing yang dirombak menjadi Arduino IDE khusus untuk pemrograman dengan Arduino pada bagian ini peneliti menggunakan software arduino yang dapat didownload dari situs resmi arduino. Adapun bentuk tampilan software arduino adalah sebagai berikut :

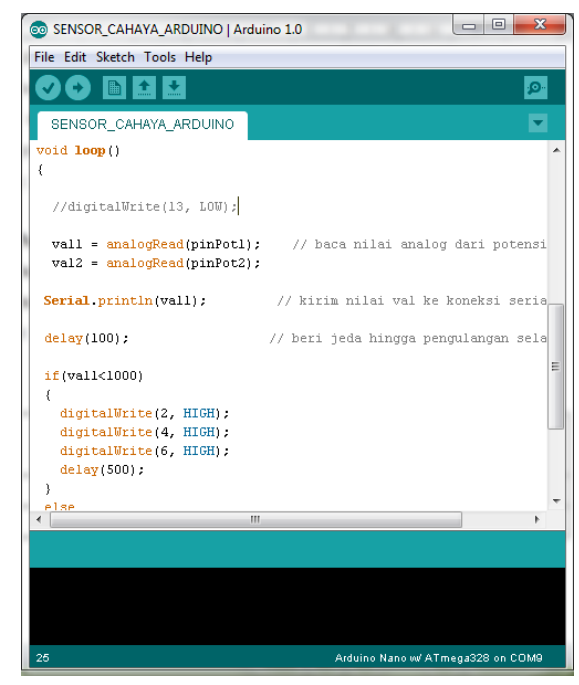

Gambar 4.2. Tampilan software Arduino

\section{Hasil}

Bahasa pemprograman yang digunakan berdasarkan pada model pemprograman dengan bahasa C. Fungsi-fungsi khusus seperti mengkompile dan mendownload program dapat dikerjakan dalam software tersebut. 


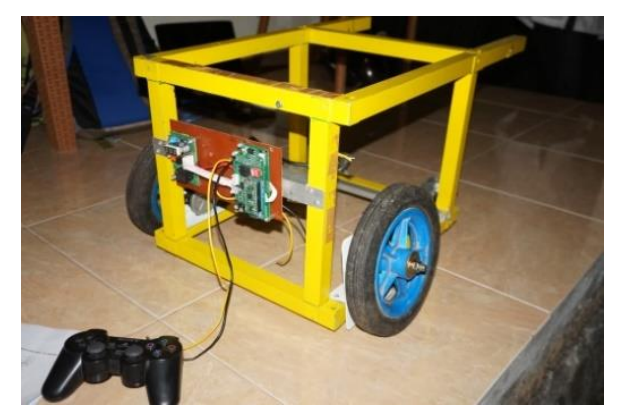

Gambar 1. Rancangan sementara mesin

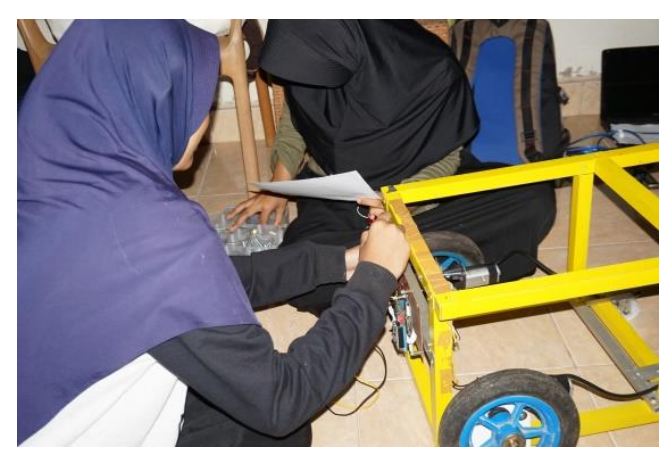

Gambar 2. Perancangan dan Pembuatan Alat

\section{Penutup}

\section{Kesimpulan}

Alat Penanam Benih padi dapat digunakan sebagai alat bantu dalam proses penanaman padi. Tegangan kerja Alat adalah $12 \mathrm{~V}$ DC dengan arus sebesar 1000mAH. Robot dapat bergerak dengan jarak kendali sejauh 10 meter.

\section{DAFTAR PUSTAKA}

Ahmad, D.R dan Haryono. 2007. Peluang Usaha Jasa Penanganan Padi Secara Mekanis Dengan Mendukung Industri Persemaian. Prosiding Seminar Nasional Apresiasi Hasil Penelitian Padi 2007. Balai Besar Penelitian Tanaman Padi.

Badan Penelitian dan Pengembangan Pertanian. 2008. Pengelolaan Tanman Terpadu (PTT) padi gogo. Badan Litbang Pertanian.

Baehaqi, S.E. 2012. Strategi pengendalian hama terpadu tanaman padi dalam praktek pertanian yang baik (Good Agricultural Practices). Pengembangan Inovasi Pertanian 2 (1), 2009: 65-78.

Wildian dan Osna, M., 2013, Sistem Penginformasi Keberadaan orang di dalam Ruang Tertutup Dengan Penampil Running Text Berbasis Mikrokontroler dan Sensor PIR (Passive Infrared), Prosiding Seminar dan Rapat Tahunan Bidang MIPA BKS PTN Wilayah Barat 2013, FMIPA Universitas Lampung, Lampung.

Nurzaman, Forzi. 2008. rancang bangun pensaklaran lampu otomatis yang terhubung dengan hp menggunakan mikrokontroler atmega8535.

Setianto, Kurniawan. 2006. pengendali lampu taman sistem telepon berbasis mikrokontroler at89s51. Universitas Negeri Semarang. 